\title{
- POZIOM WIEDZY MIESZKAŃCÓW WSI NA TEMAT CZYNNOŚCI UDZIELANIA PIERWSZEJ POMOCY
}

\author{
VILLAGERS' LEVEL OF KNOWLEDGE ON FIRST AID ACTIVITIES \\ Agata Salwa', Anna Babiarz, Grażyna Nowak-Starz ${ }^{1}$ \\ ${ }^{1}$ Instytut Zdrowia Publicznego \\ Uniwersytet Jana Kochanowskiego w Kielcach
}

DOI: https://doi.org/10.20883/pielpol.2017.61

\section{STRESZCZENIE}

Wstęp. Szybka reakcja i natychmiastowa pomoc udzielana przez przypadkowego świadka bezpośrednio na miejscu zdarzenia niejednokrotnie decyduje o przeżyciu poszkodowanego.

Cel. Celem pracy było określenie poziomu wiedzy dorosłych mieszkańców wsi w zakresie udzielania czynności pierwszej pomocy.

Materiał i metody. Badanie ankietowe zostało przeprowadzone na przełomie listopada i grudnia 2016 roku pośród pełnoletnich mieszkańców powiatu kieleckiego, województwa świętokrzyskiego. Przebadano 107 mieszkańców wsi, w tym 49 mężczyzn i 58 kobiet. Wśród badanych największą grupę stanowiły osoby w przedziale wiekowym 18-29 lat.

Wyniki. Wśród badanych najmniejszy odsetek $(11,21 \%)$ reprezentowały osoby, które znajdowały się w grupie powyżej 50 . roku życia. Spośród ogółu badanych najwyższy odsetek $(39,25 \%)$ posiadało wykształcenie zawodowe, najniższy odsetek (14,02\%) stanowiły osoby z wykształceniem podstawowym. Zdecydowana większość $(84,11 \%)$ uznała, że obowiązek udzielenia pierwszej pomocy mają wszyscy obywatele.

Wnioski. Dorośli mieszkańcy wsi wykazują przeciętny poziom wiedzy na temat czynności udzielania pierwszej pomocy. Samoocena badanych dotycząca wiedzy z zakresu czynności udzielania pierwszej pomocy jest przeciętna. Ponadto o wybranych zagadnieniach z zakresu pierwszej pomocy mieszkańcy wsi posiadają dostateczną wiedzę, a płeć, wiek, poziom wykształcenia nie wpływają w stopniu znaczącym na poziom wiedzy mieszkańców wsi na temat czynności udzielania pierwszej pomocy.

SŁOWA KLUCZOWE: pierwsza pomoc, dorośli.

\section{Wprowadzenie}

Ustawa z dnia 8 września 2006 r. o Państwowym Ratownictwie Medycznym określa zalecany czas dojazdu zespołu ratownictwa medycznego (ZRM) na miejsce zdarzenia - nie więcej niż 8 minut. W rzeczywistości jednak jest to bardzo często za mało na dotarcie do poszkodowanego. Niekorzystny wpływ na czas dojazdu ZRM ma wiele różnorakich czynników, takich jak odległość od miejsca zdarzenia czy aktualne natężenie ruchu na drogach. W związku z powyższym (w ostatnich

\begin{abstract}
Introduction. The immediate and appropriate response and the first aid provided by the bystander often influences the chances of the victim's survival.

Aim. The aim of this study was to examine the level of knowledge on the first aid.

Material and methods. The study was conducted in late November and December 2016 among adults of the Kielce district, Świętokrzyskie province. The study involved 107 people, including 49 men and 58 women. Among the respondents, the largest group were people aged 18-29.

Results. Among the respondents, the smallest percentage $(11.21 \%)$ represented people who were in the group above 50 years of age. Among all respondents the highest percentage $(39.25 \%)$ had vocational education, the lowest percentage $(14.02 \%)$ were persons with primary education. The vast majority (84.11\%) considered that all citizens had the obligation to provide the first aid.

Conclusion. Adult villagers show the average level of knowledge on first aid activities. Self-assessment of the respondents concerning the knowledge of first aid activities is average. In selected issues of the first aid, villagers have sufficient knowledge and the gender, age or level of education do not affect the level of villagers' knowledge of first aid activities.
\end{abstract}

KEYWORDS: first aid, adults.

latach) duży nacisk kładzie się na edukację obywateli w zakresie pierwszej pomocy [1].

Ustawa (...) o Państwowym Ratownictwie Medycznym zobowiązuje każdego obywatela do udzielenia pierwszej pomocy w każdej sytuacji. Wyjątkiem są tylko te okoliczności, w których zagrożone jest także życie obywatela udzielającego pomocy. Warunkuje to kilka aktów prawnych m.in.:

- $\quad$ art. 4. Ustawy z dnia 8 września 2006 r. o Państwowym Ratownictwie Medycznym (Dz.U. 2016 poz. 
1868 - Obwieszczenie Marszałka Sejmu Rzeczypospolitej Polskiej z dnia 31 października 2016 r. w sprawie ogłoszenia jednolitego tekstu ustawy o Państwowym Ratownictwie Medycznym);

- $\quad$ art. 162. Ustawy z dnia 6 czerwca 1997 r. - Kodeks karny (Dz.U. 2016 poz. 1137 - Obwieszczenie Marszałka Sejmu Rzeczypospolitej Polskiej z dnia 5 lipca 2016 r. w sprawie ogłoszenia jednolitego tekstu ustawy - Kodeks karny);

- $\quad$ art. 44. Ustawy z dnia 20 czerwca 1997 r. - Prawo o ruchu drogowym (Dz.U. 2012 poz. 1137 - Obwieszczenie Marszałka Sejmu Rzeczypospolitej Polskiej z dnia 30 sierpnia 2012 r. w sprawie ogłoszenia jednolitego tekstu ustawy - Prawo o ruchu drogowym);

- $\quad$ art. 93. Ustawy z dnia 20 maja 1971 r. - Kodeks wykroczeń (Dz.U. 2015 poz. 1094 - Obwieszczenie Marszałka Sejmu Rzeczypospolitej Polskiej z dnia 3 lipca 2015 r. w sprawie ogłoszenia jednolitego tekstu ustawy - Kodeks wykroczeń);

- $\quad$ art. 207. Ustawy z dnia 26 czerwca 1974 r. - Kodeks pracy (Dz.U. 2016 poz. 1666 - Obwieszczenie Marszałka Sejmu Rzeczypospolitej Polskiej z dnia 8 września 2016 r. w sprawie ogłoszenia jednolitego tekstu ustawy - Kodeks pracy) [1, 3-5, 13].

Reakcja i pierwsza pomoc udzielana przez przypadkowego świadka bezpośrednio na miejscu zdarzenia decyduje bardzo często o zachowaniu życia poszkodowanego. Niedostateczna wiedza na temat pierwszej pomocy bardzo często przekłada się na swoiste uczucie niemocy, a nawet strach, który nierzadko skutkuje brakiem jakiejkolwiek inicjatywy w stosunku do poszkodowanego [1, 2]. Artykuł 162 Kodeksu karnego (Dz.U. 2016, poz. 1137) jasno wskazuje, że kto osobie znajdującej się w położeniu grożącym bezpośredniemu niebezpieczeństwu utraty życia albo ciężkiego uszczerbku na zdrowiu nie udziela pomocy, mogąc jej udzielić bez narażenia siebie lub innej osoby na niebezpieczeństwo utraty życia albo ciężkiego uszczerbku na zdrowiu, podlega karze pozbawienia wolności do lat 3 [3].

Osoby wykonujące czynności w zakresie pierwszej pomocy nie powinny obawiać się odpowiedzialności karnej za niewłaściwe jej udzielenie, jeżeli wykonywały czynności ratujące życie zgodnie z posiadaną wiedzą i umiejętnościami. Osoba udzielająca pomocy lub kwalifikowanej pierwszej pomocy korzysta bowiem z ochrony przewidzianej w art. 5 Ustawy (...) o Państwowym Ratownictwie Medycznym (Dz.U. 2016, poz. 1868).

Udzielając pierwszej pomocy, można poświęcić dobro osobiste, majątkowe innej osoby, a odpowiedzialność za uszkodzenie bądź utratę mienia ponosi Skarb Państwa, co potwierdza art. 6 Ustawy (...) o Państwowym Ratownictwie Medycznym (Dz.U. 2016, poz. 1868).
Wiele osób, pomimo że odbyło szkolenia z zakresu pierwszej pomocy, waha się, czy wykorzystać swoją wiedzę w praktyce. Powodem takiego stanu rzeczy jest najczęściej brak wiary we własne umiejętności, strach przed niepowodzeniem, obawy przed złymi skutkami dla stanu zdrowia poszkodowanego, jak również strach przed zakażeniem, np. HIV czy HCV $[2,6]$.

\section{Cel pracy}

Celem pracy jest określenie poziomu wiedzy dorosłych mieszkańców wsi w zakresie udzielania czynności pierwszej pomocy. Warto nadmienić, że uwzględniono wpływ zmiennych - wieku, płci oraz poziomu wykształcenia - na poziom wiedzy z zakresu czynności pierwszej pomocy. Analizowane zostaną następujące stany zagrożenia życia: oparzenia, zatrucia, wstrząsy anafilaktyczne, złamania, porażenia prądem elektrycznym oraz nagłe zatrzymanie krążenia.

\section{Materiał i metody}

W badaniu główny problem badawczy zawarty został w pytaniu: jaki jest stan wiedzy mieszkańców wsi na temat czynności udzielania pierwszej pomocy?

Ponadto sformułowano również problemy szczegółowe, które zawierają się w następujących pytaniach:

- Jak mieszkańcy wsi oceniają stan swojej wiedzy w zakresie pierwszej pomocy?

- Jaką wiedzę mają mieszkańcy wsi o czynnościach udzielania pierwszej pomocy w wybranych stanach zagrożenia życia?

- W jakim stopniu wiek, płeć i poziom wykształcenia wpływają na zakres wiedzy o czynnościach udzielania pierwszej pomocy?

Za zmienną zależną uznano poziom wiedzy mieszkańców wsi i znajomość zasad czynności udzielania pierwszej pomocy. Jako zmienne niezależne przyjęto: płeć, wiek oraz poziom wykształcenia. Wskaźnikami dla zmiennej zależnej były wypowiedzi mieszkańców wsi dotyczące zasad czynności udzielania pierwszej pomocy. Wskaźnikami dla zmiennej niezależnej były: wiek, płeć oraz poziom wykształcenia.

W badaniu posłużono się metodą sondażu diagnostycznego. Do przeprowadzenia badań własnych jako narzędzie wykorzystano ankietę, która została skonstruowana na jego potrzebę. Ankieta zawierała metryczkę i 35 pytań zamkniętych. Badania zostały przeprowadzone na przełomie listopada i grudnia 2016 roku wśród pełnoletnich mieszkańców powiatu kieleckiego (województwo świętokrzyskie). Przebadano w sumie 107 mieszkańców wsi, w tym 49 mężczyzn i 58 kobiet. Należy również dodać, że w celu ubogacenia narracji uzyskane wyniki zostaną zestawione z wynikami wcześniej przeprowadzonych badań. 


\section{Wyniki}

Za pomocą testu chi-kwadrat zostały zbadane związki pomiędzy wiekiem, płcią, wykształceniem a wiedzą na temat zasad udzielania pierwszej pomocy. W przypadku tabel, w których wykazano istotne koligacje między zmiennymi, w celu oceny ich siły związku zastosowane zostały współczynniki V-Cramera oraz C-Pearsona.

Na podstawie wyniku testu statystycznego można stwierdzić zależność między płcią a poziomem wiedzy na temat objawów zatrucia tlenkiem węgla. Obliczona wartość $\chi^{2}$ jest większa od wartości tablicowej dla $p>$ 0,05 ; $\mathrm{df}=3$ : 10,66 > 7,81. Na podstawie uzyskanych wyników można więc stwierdzić, że płeć jest czynnikiem mającym wpływ na poziom wiedzy o objawach zatrucia tleniem węgla (Tabela 1).

Tabela 1. Płeć badanych a znajomość objawów zatrucia tlenkiem węgla Table 1. Gender of respondents and knowledge of the symptoms of carbon monoxide poisoning

\begin{tabular}{|c|c|c|c|c|c|c|}
\hline \multirow{3}{*}{$\begin{array}{c}\text { Objawy zatrucia tlenkiem } \\
\text { węgla/ } \\
\text { Symptoms of carbon monox- } \\
\text { ide poisoning }\end{array}$} & \multicolumn{6}{|c|}{ Liczba badanych/Number of subjects } \\
\hline & \multicolumn{2}{|c|}{$\begin{array}{c}\text { Mężczyźni/ } \\
\text { Men }\end{array}$} & \multicolumn{2}{|c|}{$\begin{array}{l}\text { Kobiety/ } \\
\text { Women }\end{array}$} & \multicolumn{2}{|c|}{$\begin{array}{l}\text { Razem/ } \\
\text { Together }\end{array}$} \\
\hline & $\mathrm{n}$ & $\%$ & $\mathrm{n}$ & $\%$ & $\mathrm{n}$ & $\%$ \\
\hline Bóle brzucha/Stomach ache & 2 & 1,87 & 8 & 7,47 & 10 & 9,24 \\
\hline Zawroty głowy/Dizziness & 23 & 21,49 & 12 & 11,21 & 35 & 32,70 \\
\hline Swędzenie skóry/ltchy skin & 16 & 14,95 & 20 & 18,69 & 36 & 33,64 \\
\hline Drapanie w gardle/Sore throat & 8 & 7,47 & 18 & 16,82 & 26 & 24,19 \\
\hline Razem/Together & 49 & 45,79 & 58 & 54,21 & 107 & 100,00 \\
\hline
\end{tabular}

Źródło: badania własne

Source: author's own materials

Na podstawie wyniku testu statystycznego można zaobserwować zależność pomiędzy poziomem wykształcenia a wiedzą na temat postępowania podczas zadławienia. Obliczona wartość $\chi^{2}$ jest większa od wartości tablicowej dla p > 0,05; df = 9: 27,18 > 16,92. Można zatem uznać, że poziom wykształcenia jest czynnikiem mającym wpływ na poziom wiedzy odnośnie zasad udzielania pierwszej pomocy podczas zadławienia.

Tabela 2. Poziom wykształcenia a wiedza na temat postępowania podczas zadławienia

Table 2. The level of education and knowledge of the proceedings while choking

\begin{tabular}{|c|c|c|c|c|c|c|c|c|c|c|}
\hline \multicolumn{11}{|c|}{ Liczba badanych/Number of subjects } \\
\hline \multirow{2}{*}{$\begin{array}{l}\text { Pierwsza pomoc } \\
\text { w zadławieniu/ } \\
\text { First aid for } \\
\text { choking }\end{array}$} & \multicolumn{2}{|c|}{$\begin{array}{c}\text { Wyższe/ } \\
\text { Higher }\end{array}$} & \multicolumn{2}{|c|}{$\begin{array}{l}\text { Średnie/ } \\
\text { Average }\end{array}$} & \multicolumn{2}{|c|}{$\begin{array}{l}\text { Zawodowe/ } \\
\text { Professional }\end{array}$} & \multicolumn{2}{|c|}{$\begin{array}{l}\text { Podstawo- } \\
\text { we/ } \\
\text { Basic }\end{array}$} & \multicolumn{2}{|c|}{$\begin{array}{l}\text { Razem/ } \\
\text { Together }\end{array}$} \\
\hline & $\mathrm{n}$ & $\%$ & $\mathrm{n}$ & $\%$ & $n$ & $\%$ & $\mathrm{n}$ & $\%$ & $n$ & $\%$ \\
\hline $\mathrm{A}$ & 18 & 16,82 & 20 & 18,69 & 28 & 26,17 & 11 & 10,28 & 71 & 71,9 \\
\hline B & 0 & 0 & 5 & 77 & 11 & & 4 & 3,74 & 20 & \\
\hline C & & & 11 & 10,28 & & & 0 & & 3 & \\
\hline D & & & 4 & 3,74 & 2 & 1,86 & 0 & 0,00 & t & \\
\hline $\begin{array}{l}\text { Razem } \\
\text { Together }\end{array}$ & 20 & 18,69 & 30 & 28,03 & 42 & 39,25 & 15 & 14,0 & 107 & 100,00 \\
\hline
\end{tabular}

A - położyć niemowlę na przedramieniu, twarzą w dół, wykonać uderzenia w plecy;
B - ułożyć w pozycji bezpiecznej;

C - chwycić dziecko za nogi i energicznie potrząsać;

D - natychmiast przystąpić do resuscytacji

Źródło: badania własne

Source: author's own materials

Na podstawie wyniku testu statystycznego można zaobserwować zależność pomiędzy wiekiem badanych a uczestnictwem w zajęciach z pierwszej pomocy. Obliczona wartość $\chi^{2}$ jest większa od wartości tablicowej dla $p>0,05 ; d f=3: 9,50>7,81$. Zauważyć zatem można, iż wiek jest czynnikiem mającym wpływ na uczestnictwo badanych w zajęciach z zakresu udzielania pierwszej pomocy (Tabela 3).

Tabela 3. Wiek badanych a uczestnictwo $w$ zajęciach z pierwszej pomocy Table 3. The age of respondents and participation in the course of the first aid

\begin{tabular}{|c|c|c|c|c|c|c|c|c|c|}
\hline \multicolumn{10}{|c|}{ Liczba badanych/Number of subjects } \\
\hline \multirow{2}{*}{$\begin{array}{l}\text { Udział } \\
\text { w zajęciach/ } \\
\text { Participation } \\
\text { in classes }\end{array}$} & \multicolumn{5}{|c|}{$\begin{array}{l}\text { 18.-29. r.ż.30.-39. r.ż. 40.-49. r.ż. } \\
\text { 18-29 y.o. } 30-39 \text { y.o. } 40-49 \text { y.o. }\end{array}$} & \multicolumn{2}{|c|}{$\begin{array}{l}\text { Pow. 50. r.ż. } \\
\text { More than } \\
50 \text { y.o. }\end{array}$} & \multicolumn{2}{|c|}{$\begin{array}{l}\text { Razem/ } \\
\text { Together }\end{array}$} \\
\hline & $\%$ & $\mathrm{n}$ & $\%$ & $\mathrm{n}$ & $\%$ & $\mathrm{n}$ & $\%$ & $\mathrm{n}$ & $\%$ \\
\hline Tak/Yes & 2927,10 & 17 & 15,88 & 11 & 10,28 & 8 & 7,47 & 65 & 60,75 \\
\hline Nie/No & 8,41 & 12 & 11,21 & 17 & 15,88 & 4 & 3,74 & 42 & 39,25 \\
\hline $\begin{array}{l}\text { Razem/ } \\
\text { Together }\end{array}$ & 3835,51 & 29 & 27,10 & 28 & 26,17 & 12 & 11,21 & 107 & 100,00 \\
\hline
\end{tabular}

Źródło: badania własne

Source: author's own materials

Na podstawie wyniku testu statystycznego można stwierdzić zależność pomiędzy wiekiem badanych a obecnością w sytuacji i miejscu, w której należało udzielić pierwszej pomocy. Obliczona wartość $\chi^{2}$ jest większa od wartości tablicowej dla $p>0,05 ; \mathrm{df}=3: 9,50$ $>7,81$. Na podstawie przeprowadzonych badań można stwierdzić, że wiek jest czynnikiem wpływającym na zachowanie badanych w sytuacji, w której należało udzielić pierwszej pomocy (Tabela 4).

Tabela 4. Wiek badanych a obecność w sytuacji, w której należało udzielić pierwszej pomocy

Table 4. The age of respondents and presence in a situation in which the first aid should have been provided

\begin{tabular}{|c|c|c|c|c|c|c|c|c|c|c|}
\hline \multirow{3}{*}{$\begin{array}{l}\text { Sytuacja/ } \\
\text { Situation }\end{array}$} & \multicolumn{10}{|c|}{ Liczba badanych/Number of respondents } \\
\hline & & $\begin{array}{l}\text { 29. r.ż. } \\
29 \text { y.o. }\end{array}$ & $\begin{array}{l}30 .- \\
30-\end{array}$ & $\begin{array}{l}\text { 39. r.ż. } \\
39 \text { y.o. }\end{array}$ & $\begin{array}{l}40 .- \\
40-\end{array}$ & $\begin{array}{l}\text { 49. r.z.z. } \\
\text { 19 y.o. }\end{array}$ & $\begin{array}{r}\text { Pow. } \\
\text { Mol } \\
50\end{array}$ & $\begin{array}{l}\text { 50. r.ż. } \\
\text { e than } \\
\text { y.o. }\end{array}$ & & $\begin{array}{l}\text { zem/ } \\
\text { yether }\end{array}$ \\
\hline & $\mathrm{n}$ & $\%$ & $\mathrm{n}$ & $\%$ & $\mathrm{n}$ & $\%$ & $\mathrm{n}$ & $\%$ & $\mathrm{n}$ & $\%$ \\
\hline Tak/Yes & 14 & 13,08 & 11 & 10,28 & 8 & 7,47 & 8 & 7,47 & 41 & 38,31 \\
\hline Nie/No & 24 & 22,42 & 18 & 16,82 & 20 & 18,69 & 4 & 3,74 & 66 & 61,69 \\
\hline $\begin{array}{l}\text { Razem/ } \\
\text { Together }\end{array}$ & 38 & 35,51 & 29 & 27,10 & 28 & 26,17 & 12 & 11,21 & 107 & 100,00 \\
\hline
\end{tabular}

Źródło: badania własne

Source: author's own materials 
Na podstawie wyniku testu statystycznego można odnotować zależność między wiekiem badanych a wiedzą na temat stosunku uciśnięć klatki piersiowej i oddechów podczas resuscytacji krążeniowo-oddechowej u noworodków. Obliczona wartość $\chi^{2}$ jest większa od wartości tablicowej dla $p>0,05 ; \mathrm{df}=3: 17,89>16,92$. Uzyskane wyniki uprawniają do stwierdzenia, że wiek może być czynnikiem wpływającym na poziom wiedzy na temat stosunku uciśnięć klatki piersiowej i oddechów podczas resuscytacji krążeniowo-oddechowej (RKO) u noworodków (Tabela 5).

Tabela 5. Wiek badanych a wiedza na temat stosunku uciśnięć klatki piersiowej i oddechów podczas RKO noworodków

Table 5. The age of respondents and knowledge of the ratio of chest compressions and breaths during the newborns' $C P R$

\begin{tabular}{|c|c|c|c|c|c|c|c|c|c|c|}
\hline \multirow{3}{*}{$\begin{array}{l}\text { Stosunek } \\
\text { uciśnięćl } \\
\text { The ratio } \\
\text { of compressions } \\
\end{array}$} & \multicolumn{10}{|c|}{ Liczba badanych/Number of respondents } \\
\hline & \multicolumn{6}{|c|}{$\begin{array}{l}\text { 18.-29. r.ż. 30-39. r.ż. 40.-49. r.ż. } \\
\text { 18-29 y.o. } 30-39 \text { y.o. } 40-49 \text { y.o. }\end{array}$} & \multicolumn{2}{|c|}{$\begin{array}{l}\text { Pow. 50. r.ż. } \\
\text { More than } \\
50 \text { y.o. }\end{array}$} & \multicolumn{2}{|c|}{$\begin{array}{l}\text { Razem/ } \\
\text { Together }\end{array}$} \\
\hline & $n$ & $\%$ & $\mathrm{n}$ & $\%$ & $\mathrm{n}$ & $\%$ & $\mathrm{n}$ & $\%$ & $\mathrm{n}$ & $\%$ \\
\hline & 8 & 7,47 & 13 & 12,1 & 7 & & & & 33 & 30,84 \\
\hline & 18 & 17,7 & 11 & 10,28 & 17 & & & & 54 & 50,46 \\
\hline & 7 & 6,54 & 2 & 1,86 & 4 & & 0 & & 12 & 11,21 \\
\hline & & & 3 & 2,80 & & & & & & 7,48 \\
\hline $\begin{array}{l}\text { Razem/ } \\
\text { Together }\end{array}$ & 38 & 35,51 & 29 & 27,10 & 28 & 26,17 & 12 & 11,21 & 107 & 100,00 \\
\hline
\end{tabular}

Źródło: badania własne

Source: author's own materials

\section{Dyskusja}

Jak wynika z badania, około $40 \%$ osób nim objętych ocenia swoją wiedzę na temat udzielania pierwszej pomocy jako przeciętną. Niepokojącym faktem jest stosunkowo niski odsetek badanych z bardzo dobrą samooceną - 14\% respondentów. Niewiele mniej, bo 12\%, określa swoją wiedzę poniżej przeciętnej.

Badania przeprowadzone przez Wiśniewskiego i Majewskiego wśród grupy nauczycieli również wykazały, iż badani słabo oceniają swoją wiedzę w omawianym w niniejszym tekście zakresie [7]. Jest to o tyle ciekawe, że wyniki badań przeprowadzonych przez autorki prezentowanego artykułu wskazują, że ponad $60 \%$ respondentów deklaruje udział w kursach, szkoleniach z pierwszej pomocy. Z kolei $40 \%$ badanych nie uczestniczyło w zajęciach z pierwszej pomocy. Na tej podstawie można wywnioskować, iż zasięg przeprowadzanych szkoleń jest zbyt niski, a ich skala - zbyt mała.

W badaniach studentów aglomeracji trójmiejskiej przeprowadzonych przez Strzyżewską, Mędrzycką-Dąbrowską, Dąbrowskiego i Basińskiego wykazano, że większość badanych (84\%) uczestniczyła w szkoleniach z zakresu pierwszej pomocy [12]. W sytuacji, w której należało udzielić innej osobie pierwszej pomocy, uczestniczyło ponad $60 \%$ osób objętych sondażem. Jak wynika z analizy badań własnych, 38\% osób nie znalazło się w takiej sytuacji. Natomiast analiza wyników badań przeprowadzonych przez Bilewicz-Wyrozumską, Rybarczyk, Lara i wsp. wskazuje na fakt, iż większości nie zdarzyło się znaleźć w sytuacji, która wymagała udzielenia pierwszej pomocy [8].

Z badań autorek niniejszego opracowania wynika, że $95 \%$ badanych zna numer alarmowy pogotowia ratunkowego. Odsetek osób, które mylnie wybrały numer policji lub straży pożarnej, wynosi 5\%. Wśród grupy aktywnych kierowców 88\% wybrało numer 999, jednak aż 12\% błędnie wybrało telefon 998 bądź 997 [10].

Należy w tym miejscu zauważyć, iż $70 \%$ badanych zna stosunek uciśnięć klatki piersiowej do liczby oddechów. Jest to wynik wyższy od tego uzyskanego przez personel pedagogiczny w Siemianowicach Śląskich [8]. Stanowczo gorzej niniejszy stosunek znają nauczyciele z zachodniopomorskiego - prawidłowych odpowiedzi udzieliło tylko $13 \%$ badanych [7].

Znacznie mniejszą wiedzą wykazali się badani na temat zastosowania pozycji bocznej, tzw. pozycji bezpiecznej. Połowa badanych uznała, że w pozycji bezpiecznej układa się poszkodowanego nieprzytomnego, a oddychającego. Wśród badanych nauczycieli 50\% wiedziało, co to jest pozycja boczna bezpieczna, a 33\% wiedziało, w jakim celu się ją stosuje [11].

Według wytycznych Europejskiej Rady Resuscytacji z 2015 roku ocena oddechu za pomocą wzroku, słuchu i dotyku u poszkodowanego winna trwać nie więcej niż 10 sekund. Oceny oddechu u poszkodowanego (według badanych) należy dokonać, przybliżając policzek do ust poszkodowanego i obserwując ruchy klatki piersiowej. Takiej odpowiedzi udzieliło $70 \%$ ankietowanych, 44\% respondentów wie, że ocena oddechu winna trwać 10 sekund. Zdecydowana większość (99\%) aktywnych kierowców zadeklarowała, iż potrafi ocenić obecność oddechu; 56\% spośród nich wie, jak długo powinna trwać ocena oddechu [9].

Wyniki badań wskazują, że ankietowani wiedzą, iż oceny tętna u osoby dorosłej dokonuje się na tętnicy szyjnej $(80,37 \%)$. Potwierdzają to badania Wiśniewskiego i Majewskiego wśród grupy nauczycieli szkół ponadgimnazjalnych w Wielkopolsce [7].

Z badań autorek niniejszej pracy wynika, iż $21 \%$ badanych spotkało się z urządzeniem AED - automatycznym defibrylatorem zewnętrznym. Najczęściej urządzenie AED spotkano w kinie, na zakupach, w parku i w innych miejscach, których badani nie określili. Warto w tym miejscu zaznaczyć, że odpowiednio szybko rozpoczęte przez świadków zdarzenia RKO oraz wczesna defibrylacja znacząco zwiększają szanse przeżycia.

W badaniach autorek niniejszej pracy $76 \%$ ankietowanych uznało, że podczas napadu drgawek należy zabezpieczyć głowę przed uderzeniami. Natomiast przytrzymywanie „na siłę” ciała poszkodowanego czy zabezpieczenie języka przed przygryzieniem (np. poprzez włożenie do ust zwiniętej chusteczki) zostało przez $24 \%$ 
badanych określone negatywnie. W badaniach przeprowadzonych wśród nauczycieli (Bilewicz-Wyrozumska, Rybarczak, Lar i wsp.) prawidłowej odpowiedzi w powyższym zakresie udzieliło prawie 53\% badanych. Wśród osób, które w założeniu mają w pierwszej kolejności udzielić pomocy uczniom, wydaje się to być dość niski procent. Natomiast 7\% nauczycieli szkół ponadgimnazjalnych w sytuacji napadu drgawek u ucznia wezwałoby jedynie pomoc, nie znając zasad pierwszej pomocy na miejscu zdarzenia [8].

W ciąży powyżej 20. tygodnia powiększona macica może powodować ucisk na żyłę główną dolną i aortę, powodując zmniejszenie powrotu żylnego i rzut serca, co może powodować spadek ciśnienia oraz wstrząs. Takie objawy mogą przyśpieszyć zatrzymanie krążenia, dlatego kluczowym elementem resuscytacji kobiety ciężarnej jest dodatkowe pochylenie kobiety ciężarnej na lewy bok, podkładając klin pod bok prawy. W badaniach własnych odpowiedzi takiej udzieliło niespełna $46 \%$ badanych [12].

Jak wskazują wyniki badań, częstym powikłaniem masażu serca jest złamanie żeber (64\%), zaburzenia rytmu serca (15\%) oraz uszkodzenie mięśnia sercowego (15\%).

Niewiele trudności badanym sprawiło założenie opatrunku podczas krwawienia. Ponad $83 \%$ badanych zastosowałoby opatrunek uciskowy. Znacznie gorzej wypadli badani nauczyciele - wiedzę dotyczącą zastosowania opatrunku uciskowego posiada niewiele ponad $30 \%$ z nich [7].

Uzyskane wyniki badań pozwalają sformułować stwierdzenie, że zarówno dorośli mieszkańcy wsi, jak i inne grupy społeczeństwa w znacznym stopniu nie potrafią udzielić pierwszej pomocy w odpowiednim zakresie. Główną przyczyną takiego stanu rzeczy są obawy (strach) przed pogorszeniem stanu zdrowia poszkodowanego. Porównując postawy dorosłych mieszkańców wsi z badaniami innych autorów, stwierdzić można, iż wiedza mieszkańców powiatu kieleckiego na temat pierwszej pomocy jest niewystarczająca. Ankietowani pomimo przebytych szkoleń niechętnie pogłębiają swoją wiedzę w tym zakresie. Najczęściej określają swoją wiedzę jako „przeciętną” i taką też wykazali się w pytaniach teoretycznych. Należy jednak zauważyć, że mankamentem prowadzonych badań była faktyczna niemożność praktycznego sprawdzenia umiejętności badanych w zakresie udzielania pierwszej pomocy.

\section{Wnioski}

Przeprowadzone badania i otrzymane wyniki pozwoliły na sformułowanie następujących wniosków:

1. Dorośli mieszkańcy wsi wykazują przeciętny poziom wiedzy na temat czynności pierwszej pomocy.

2. Samoocena badanych dotycząca wiedzy o czynnościach udzielania pierwszej pomocy jest przeciętna.

3. W wybranych zagadnieniach z zakresu udzielania pierwszej pomocy mieszkańcy wsi posiadają dostateczną wiedzę.
4. Płeć, wiek, poziom wykształcenia nie wpływają w znaczącym stopniu na poziom wiedzy mieszkańców wsi na temat czynności udzielania pierwszej pomocy.

\section{Piśmiennictwo}

1. Obwieszczenie Marszałka Sejmu Rzeczypospolitej Polskiej z dnia 31 października 2016 r. w sprawie ogłoszenia jednolitego tekstu ustawy o Państwowym Ratownictwie Medycznym. Dz.U. 2016 poz. 1868.

2. (Dostępne w Internecie:) http://statystyka.policja.pl/ (data dostępu: 5.02.2015).

3. Obwieszczenie Marszałka Sejmu Rzeczypospolitej Polskiej z dnia 5 lipca 2016 r. w sprawie ogłoszenia jednolitego tekstu ustawy - Kodeks karny. Dz.U. 2016 poz. 1137.

4. Obwieszczenie Marszałka Sejmu Rzeczypospolitej Polskiej z dnia 30 sierpnia 2012 r. w sprawie ogłoszenia jednolitego tekstu ustawy - Prawo o ruchu drogowym. Dz.U. 2012 poz. 1137.

5. Obwieszczenie Marszałka Sejmu Rzeczypospolitej Polskiej z dnia 3 lipca 2015 r. w sprawie ogłoszenia jednolitego tekstu ustawy - Kodeks wykroczeń. Dz.U. 2015 poz. 1094.

6. Frąckowiak K, Świder P. Odpowiedzialność karna i dyscyplinarna osób wykonujących zawody medyczne za nieudzielenie pomocy ofiarom wypadków drogowych. Zeszyty Naukowe Wyższej Szkoły Informatyki, Zarządzania i Administracji. 2013; 25, 4: 81-95.

7. Wiśniewski J, Majewski WD. Ocena poziomu wiedzy nauczycieli szkół ponadgimnazjalnych w Zachodniopomorskiem na temat pierwszej pomocy medycznej. Rocz PAM. 2007; 53: 114-123.

8. Bilewicz-Wyrozumska T, Rybarczyk J, Lar K et al. Znajomość zasad udzielania pierwszej pomocy wśród nauczycieli. Zdrowie i Dobrostan. 2014; 1: 9-22.

9. Patryn R, Żyśko M, Sobczyńska M. Analiza poziomu wiedzy i znajomość prawa dotyczącego zasad udzielania pierwszej pomocy wśród grupy aktywnych kierowców województwa lubelskiego. Med Ogólna Nauki Zdr. 2012; 18: 324-329.

10. Szpringer M, Komendacka O, Kosecka J, Sobczyk B. Ocena wiedzy kierowców na temat zasad udzielania pierwszej pomocy. Med Ogólna Nauki Zdr. 2014; 20: 260-264.

11. Skitek I, Witt M, Goniewicz M. Assessment of the first aid knowledge among Poznań university students. Now Lek. 2012; 81: 641-646.

12. Strzyżewska K, Mędrzycka-Dąbrowska W, Dąbrowski S, Basiński A. Assessment of the level of knowledge about delivering first aid in emergency situations among students of Tri-city Metropolitan Area Colleges. Anest Ratow. 2012; 6: 41-52.

13. Obwieszczenie Marszałka Sejmu Rzeczypospolitej Polskiej z dnia 8 września 2016 r. w sprawie ogłoszenia jednolitego tekstu ustawy - Kodeks pracy. Dz.U. 2016 poz. 1666.

Artykuł przyjęty do redakcji: 18.11.2016

Artykuł przyjęty do publikacji: 14.01.2017

Źródło finansowania: Praca nie jest finansowana z żadnego źródła. Konflikt interesów: Autorzy deklarują brak konfliktu interesów.

Adres do korespondencji:
Agata Salwa
Brynica 19
26-062 Piekoszów
tel. kom.: 530168129
e-mail: salwaagatka@gmail.com
Instytut Zdrowia Publicznego
Uniwersytet Jana Kochanowskiego w Kielcach

